\title{
Expression and Diction
}

Author(s): Agnes J. Larkcom

Source: The Musical Times, Vol. 61, No. 927 (May 1, 1920), pp. 299-302

Published by: Musical Times Publications Ltd.

Stable URL: http://www.jstor.org/stable/909929

Accessed: 15-04-2016 04:22 UTC

Your use of the JSTOR archive indicates your acceptance of the Terms \& Conditions of Use, available at

http://about.jstor.org/terms

JSTOR is a not-for-profit service that helps scholars, researchers, and students discover, use, and build upon a wide range of content in a trusted digital archive. We use information technology and tools to increase productivity and facilitate new forms of scholarship. For more information about JSTOR, please contact support@jstor.org.

Musical Times Publications Ltd. is collaborating with JSTOR to digitize, preserve and extend access to The Musical Times 
which has already been foreshadowed in (a) and (e). This is given out by a solo trumpet under a high tremolo of divisi strings. Purely diatonic harmonies are used, but a delightful colour is obtained by pizzicato strings in unison with the trumpet, and a short figure on the celesta, imitated by the flutes. The beautiful theme deserves special study, as the whole genius of the work is centred in it. Attention may be drawn to :

(a) Its simple diatonic nature and obvious suitability for development;

(b) Its perfect balance, combined with an absence of squareness of rhythm ;

(c) Its characteristic octave leaps.

The three following variations consist of a repetition of the theme without change of key or rhythm, but with contrasted orchestration. In each case the first bar of the new variation overlaps the cadence of the previous one. The tonality and theme having been well establi,shed, the remaining variations proceed to throw new light on the latter from many points of view, and it is developed through continuous changes of rhythm, tempo, and tonality. It would be idle to attempt to follow this in detail within the limitations of this article. The work must be heard. Its outstanding feature is continuity of evolution, a quality that can hardly be conveyed in a written description, and one to which the Variations owe much of their greatness.

Attention may be directed to a few outstanding points. Variations Nos. 6 and 7 are in free rhythm, the time-signatures employing 3-4, 4-4, 5-4 and 2-4 tempi, and changing in nearly every bar. A variant of the theme from this section is used in the Fugue in the Finale. Part of the exposition of this is given in $(g)$. Nos. 8 and 9, in waltz rhythms, are comparatively lightly scored, and take the place of a Scherzo in a Symphony. No. Io is built on a ground bass of the first three notes of the theme, repeated by the trombones. Nos. I 6 and $\mathrm{I} 7$ are of an Oriental atmosphere, with a repeated figure on the Indian drum and effective short solos for violin and 'cello.

In No. I 8 much is heard of the harp, celesta, glockenspiel, and triangle in combination. This leads into the Finale. Here a new colour is introduced by the xylophone-a rare visitor in serious scores-and further extended use is made of all the percussion instruments playing piano. A reprise of motifs from the various sections works up to the biggest climax of the work, molto appassionato. This is followed by a fugal treatment of the variant of the theme to which reference has already been made :

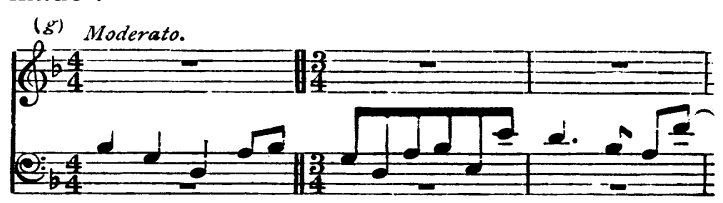

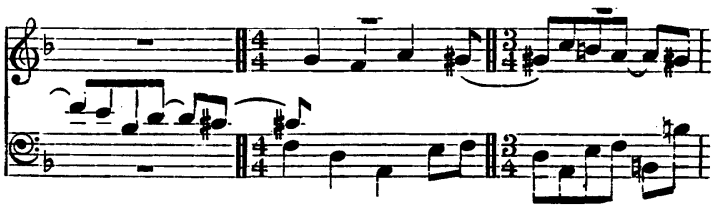
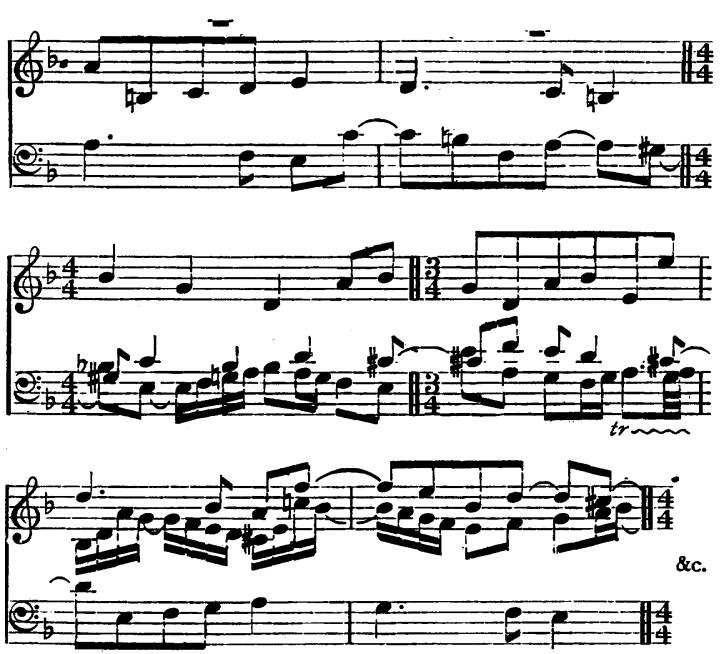

After some further working out, a long diminuendo leads to a pianissimo restatement of the theme on the flute, with the lightest possible accompaniment. With this, so to speak, tender farewell to the theme, a masterly work ends.

$$
\text { (To be continued.) }
$$

\section{EXPRESSION AND DICTION}

\section{By Agnes J. Larkcom}

The art of expression rests entirely upon sympathy and understanding. It should be studied from first principles, and not from isolated examples of poetry and music. Words and musical signs are inadequate to convey all the meaning which lies behind the concrete signs and symbols. Only by insight and imagination can we ever hope to interpret the real meaning of great poets and musicians. Our ambition ought to be to train and develop our resources until we are able in some degree to enter into their state of mind, to see from their point of view, share their emotions, and rise to their ideals. If we accept this conclusion, it will be seen at once that no one can adequately express the ideas of the great unless he has the germs of their ideas in himself. It is hopeless for the mean, limited, and coarse to think they can ever put before us the measure of the refined and lofty soul. The mirror only reflects perfectly when it is true-the string only responds to its own period of vibration.

A fine artist interpreter, then, may be considered to contain in himself the same kind of capacities for feeling and expression as those which animate the creative genius whose works he seeks to interpret. The latter is probably more specially gifted in power of observation, concentration, 
constructive ability, and skill in statement; but the differences cannot be great in kind, though they may be considerable in degree. It is pitiful to see the frivolous, petty, uneducated singer or performer struggling with the masterpieces of Art. He can never reach their heights. Imagination, character, and education are the first necessities for the student of really fine art, and we need not concern ourselves with the wants of those whose ambitions are satisfied with lower levels of achievement.

It is somewhat difficult to define 'beauty' or explain what is meant by a work of fine art. People often say: 'Beauty is only a conventionone person thinks a thing beautiful which another considers hideous.' Yet beauty is very real indeed. The much-quoted line of Keats: 'A thing of beauty is a joy for ever,' may perhaps give us the solution of the problem. Those things are beautiful which stimulate the higher emotions and give us that ineffable uplifted sensation of which we are all conscious at times. It is the kind of rapture we experience when in the presence of some of the marvels of nature, or when we are impressed by the wonderful majesty of noble architecture, fine music, or inspired poetry. For a brief space something exquisite seems to be added to life which no amount of physical pleasure can ever give. It is the momentary union of the spirit with the ideal and the infinite, towards which it blindly and feebly gropes through the greater part of existence.

When this stimulation and exaltation are caused by seeing or hearing or understanding something produced by human agency, we can consider that production to be a work of fine art.

I have spoken of education as being necessary to the interpretative artist, and side by side with education of the mind must go the training of the physical organs employed in voice-production. After the lungs and throat have been developed and strengthened, the articulatory organs need very definite attention from the singer. Good and beautiful diction is interpretation's skilled handmaiden. By diction I mean the correct pronunciation and clear enunciation of words, added to a way of expressing them which conveys their full spiritual value clearly and truly to the mind of the listener. Words may be sung distinctly but not beautifully, beautifully but not distinctly, or both beautifully and distinctly but not expressively. Occasionally when listening to some of the shining lights of the music-hall stage I have been amazed and perhaps envious of the sharp clearness with which every word fell on the ear, while at the same time the effect was often ugly and unpleasant. Clarity alone does not satisfy us. Words seem to have a life of their own. Every inflection of the voice affects their importance.

Mood is suggested by the colour of the vowels, but consonants are the real means of expression. Every emotion affects the physical condition more or less, and the results of that affection are apparent in the way we enunciate our words.
The vocal artist must study the effects of emotion on the articulatory organs, and by careful observation and practice become capable of reproducing at will the same conditions as those which are the spontaneous outcome of real feeling.

The letters of the English alphabet can be roughly divided into three groups. These overlap a little, but are good enough to work from. The first group contains all the vowels or sound carriers. A vowel technically is a vocal sound that passes through a tube which varies in shape but is always open and unobstructed. The second group includes all the voiced consonants, i.e., the consonants which need vocal tone to form them, but which are always heard through an obstruction such as the lips in $m$, the tongue and teeth in th, the teeth and lower lip in $v$, \&c., \&c.

The third group includes the aspirates, hisses, and nearly all the explosives, such as $s, s h, f, t, p$, $k, c h$. It will be noticed that these are little noises which interrupt the flow of vocal continuity. The few consonants which do not quite fall into these groups are $b, d, g$, and $j$. These are explosives, but have a faint vocal quality. They are not sustainable. The student ought to practise these instruments of expression separately, assiduously, and carefully. The colour of vowels should be varied, and different degrees of length and energy should be given to the consonants until they become his perfect and obedient servants.

A good deal of beautiful vocal expression is the result of intuitive feeling and sympathy, but I think the teacher ought to study the expression of the emotions scientifically. Such things as love, joy, fear, anger, and indignation have signs with which we are all familiar. Language is full of such expressions as: 'Her face relaxed into a smile'; 'His face contracted into a frown'; 'He set his teeth and clenched his hands with rage,' \&c. Rage and anger are accompanied by the contraction which precedes a spring or violent movement. Fear is shown by shrinking, joy by a kind of expansion, while all the soft and sympathetic emotions are accompanied by a state of relaxation and flexibility. One or two examples may be useful. Watch a mother fondling a little child. Each movement is tender and gentle so as not to cause the least discomfort. Every muscle seems to become a soft pillow for the darling little head or limbs. Then the voice-the vowels take on an added roundness and sweetness; the voiced consonants are dwelt on and prolonged, while the explosives are softened down or completely suppressed. How familiar are we with the lisping baby-talk of a fond mother, and how instinctively in our turn we all resort to it!

We can also see the soothing effects of rocking, rhythmic movements. Sudden noises, harsh sounds, and stiff positions are all foreign to the expression of love and protective tenderness.

How different is the expression of anger ! When we are indignant, whether for good or evil reasons, we want to do something. There is first a drawing together rigidly, a momentary pause, 
then the sound bursts forth. The explosive con- tion of their possibilities. He will avoid fatigue sonants shake, and arouse, and excite. Everything by making the most of the vowels and voiced tends to disturb tranquillity and inspire to action. consonants, and so never break off the sound Then fear: This emotion is accompanied by an unnecessarily. If these directions are followed, it instinctive desire not to be seen or heard. We will be found that English is one of the best shrink physically, and if obliged to speak, resort to languages for the singer. It is clear, strong, the use of such words as do not need or involve varied, and musical, and there is no reason the use of much vocal power. Soft hisses and why it should be mouthed and distorted as it so aspirates are used-every sound that does not frequently is. English possesses the unique travel far. Round, rich vowels need broad, open advantage of being a blend of two widely differing resonators. The sensation of fear makes contrac- types of speech-Latin and Teutonic. It can tion inevitable, so every vowel will reflect a express the sweetness and subtlety of the south as weakened resonance, and consonants which need easily as the strength and vitality of the north. energetic movements will be kept in the back- The people of a country make the idiom, and the ground.

The sentiment of awe is allied to that of fear, but is not quite the same-it includes reverence. In 'Elijah' the words of the Angel: 'Thy face must be veiled, for He draweth near,' always seem to me to suggest the complex feeling of awe very beautifully. How the idea of the nearness of God can be made to envelop us by the sensitive appreciation of a reverent artist-how thrilling are the words when they drop from the lips of a great singer!

The technical study of letters and words reminds us that it is customary to speak of some languages as being 'vocal' or easy to sing, and some as being unvocal or tiring. Modern languages are generally classified as to their 'vocal' position in this order: Italian, French, English, German. This is fairly correct, but I am inclined to say that English is very little, if at all, less vocal than Italian or French, provided it is properly practised and its possibilities understood. The language which is easiest to sing will be found to be one in which vowel sounds predominate; that which is most difficult, the one which possesses most of those consonants which involve a break of vocal continuity. It is not the continuous effort that tires so much as the starting and stopping of a move ment. We know this is the case in everythingeven a simple walk will be fatiguing if we constantly stop and go on again. When this happens in singing there is a little jerk of the larynx which, if frequently repeated, will tire the throat and make us uncomfortable.

The reason I have for advocating the necessity for practising the voiced consonants is that, not only are they most effective and useful means of expression, but when properly sung they do not interfere with the continuity of vocal effort, and they render English easy and agreeable to sing. English is rich in vowels (it possesses six more than Italian and only three less than French). Most of the faults met with in English singers' diction arise from a want of interest in and appreciation of the beauties of their own tongue which is characteristically British. Hence the common idea that English is difficult to sing. It the pupil should therefore be turned towards all is not; it becomes so only from ignorance and that is good, beautiful, and interesting in life, art, inattention. The wise singer will study vowels and science. His energies should not be entirely with loving care, voiced consonants with tender absorbed in his own special study. The good regard, and the other consonants with due apprecia- teacher should not seek to impose his own 
individuality on that of the student, but should elect of musical history. It is the song 'L'Amour strive to awaken interest, stimulate activity, and de Moy,' which is sometimes, but quite erroneously, point the way towards the path of self-development, described as a folk-tune. Its essentially aristocratic or as Maria Montessori beautifully puts it, ' $\mathrm{He}$ character should have sufficed to show that its should show a light and pass on his way.'

\section{MODERN BRITISH COMPOSERS}

\section{By Edwin Evans}

\section{X.-Ralph Vaughan Williams (contd.)}

It is impossible to pass in review the works of Vaughan Williams in the chronological order which furnishes so useful a plan with other composers. In the first place, whereas their development has been consistent in the sense that their various musical ideas have marched as it were abreast, Vaughan Williams's progress has been less ordered. In some aspects his work at a very early date shows an astonishing finality, whilst in others it still lacks to-day the finish that we expect to find in a composer at his stage of maturity. Moreover, his passion for revision leaves us constantly in doubt concerning the date of certain of his most characteristic works. Should they be assigned to the year in which they originated, or to that in which they reached their present form? Even when they have been standardised by publication, it does not always follow that their evolution is terminated. No order in which we could place them would present his compositions in such a sequence as would constitute in itself a biography of his musical life, and the variety of his musical experience defies systematic classification. It is one of those rare instances in which the apparently fortuitous selection of more or less cognate suggestions.offers the prospect of a result at least as illuminating as any logical process.

In the preceding article we arrived at a group of his early songs, which furnishes as good a starting-point as any other. Generally speaking his songs reached print more rapidly than any of his other works, and this arrested the process of revision. But on examining them carefully, we realise that it is precisely his songs which furnished the least occasion for afterthought. Though not each one of them is perfect in itself, all of them convey a convincing impression that they are an adequate presentment of the musical thought as it came to him. This is an impression that we do not always derive even from his most deliberate work in other spheres, where we are constantly assailed by doubts whether he could not have given fuller expression to what was in his mind-doubts, by the way, which the composer himself constantly shares. Two other songs of early date deserve mention, 'Orpheus with his lute,' for its old-world charm, and 'Boy Johnny,' for its simple directness. Then followed the 'Songs of Travel,' of which the first book contains the most popular, which are 'The Vagabond,' 'Bright is the Ring of Words' and 'The Roadside Fire.'. About the same time he arranged two old French songs, one of which has a melody which places its anonymous author among the origin could not be the popular Muse. But there is a general tendency to regard all the songs of old France, not excluding even those which can be traced to the Troubadours, as folk-songs, equally with those whose rustic character is obvious. No peasant, or other untutored man of the people, has ever sung such a song as 'L'Amour de Moy.'

Not long afterwards, Vaughan Williams harmonized two volumes belonging to the series 'Folk-Songs of England ' issued by Messrs. Novello. Here I find myself on somewhat dangerous ground, for the mode of accompaniment is very different from that which appeals to my personal taste. But while frankly saying so, I am not blind to the sterling quality of the method which the composer has applied, viewing these songs from another angle. It is only the fanatics of the folksong world who arrogate to themselves the right of declaring how these old melodies should be set, and the example they give of exclusiveness is one to be avoided. Vaughan Williams gives the songs a becoming sturdiness, and preserves their original character, some of which would have had to be sacrificed had he considered it necessary to accommodate them to the purposes of ordinary song. That he has been uncompromising with the songs themselves is a circumstance that I bow to, but I wish that he could have compromised more in favour of the instrument for which the accompaniments are written. They are good intrinsically, but few of them make an effective use of pianistic resource, such as for instance Moullé has employed in his 'Songs of Normandy,' which are a classic in the genre.

The next important work in song form was the cycle 'On Wenlock Edge,' to which I devoted an article in these columns in June, I 9 I 8 . It consists of six poems selected from Housman's 'A Shropshire Lad,' and set for voice with string quartet and pianoforte. This remarkable composition dates from the composer's association with Ravel, of which there are subtle traces in most of the songs, and a more obvious one in 'Bredon Hill.' Yet this extraneous influence is so completely confined to what one may term the scenic accessories of the music that, even were it most apparent, it carries with it no feeling of intrusion. One of the mysteries of our English musical life of ten years ago was, however, that a composer might model himself upon certain approved German classics and not incur reproach for following what was then considered to be the right and proper course, but if he had the audacity to profit by experience of another source, it was considered a lapse from virtue. Happily we are forgetting those prejudices, and they are only worth mentioning as historical curiosities. For that matter, 'On Wenlock Edge,' like any other music, has its genealogy, with a collateral branch extending even into Germany, but in a more intimate sense it is almost as English 